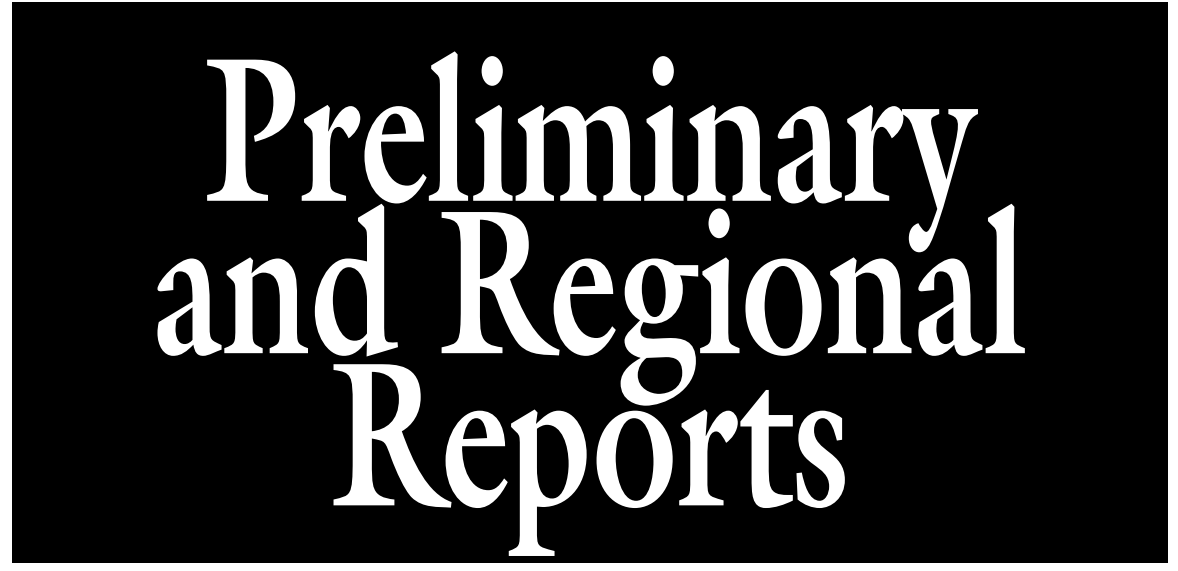

\title{
Overwintering Survival and Vigor of Container- grown Fountain Grass: Influence of Substrate Moisture Content, Protective Covers, and Fertilizer Rate
}

\author{
William K. Harris, Joyce G. Latimer, John F. Freeborn, \\ Margaret Aiken, and Holly L. Scoggins ${ }^{1}$
}

AdDitional INDEX words. Pennisetum alopecuroides, cold hardiness, perennial, ornamental grass, nursery production

Summary. Despite the popularity of fountain grass (Pennisetum alopecuroides) as a landscape perennial, little research has been conducted on nursery management practices that maximize its overwintering survival and subsequent spring vigor in container production systems. An experiment was conducted to determine the effect of protective covers (a double layer of insulation fabric, a double layer of insulation fabric plus a single sheet of white polyethylene plastic, or no cover), fertilizer application rate (high and low), and substrate moisture content (irrigated when substrate volumetric water content (VWC) fell below $15 \%$ and $25 \%$ ) on the survival rate and vigor of container-grown fountain grass: straight species fountain grass (SFG), 'Hameln' fountain grass (HFG), and 'Little Bunny' fountain grass (LBFG). Plants were overwintered in a coldframe and were evaluated for survival rate (percent that survived the winter) and vigor (visual rating scale 1 to 5 ) the following spring. Survival rate and vigor ratings varied among species. However, the highest survival rates (generally $75 \%$ or greater) and vigor ratings (generally 3 or greater) were in treatments that used protective covers, though there was not a clear advantage to using white polyethylene in addition to the double layer of insulation fabric. In treatments that used either of the protective covering methods and the high fertilizer application rate, $25 \%$ or less of LBFG survived and had vigor ratings of 1.3 or less. In contrast, $75 \%$ of LBFG survived when the low fertilizer rate was used in conjunction with either protective covering method. Substrate moisture content only affected the survival rates of SFG and HFG when no protective cover was used, although these survival rates were less than those with covers. These results suggest that protective covers may serve as a tool to minimize winter damage and improve crop quality for the species used in this trial. Because of the varied capacity among these cultivars to tolerate different fertilizer rates and substrate moisture contents, it is recommended that growers use the results of this study as a baseline for conducting site evaluations to determine overwintering techniques that maximize survival and vigor on their facilities.

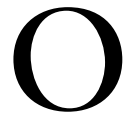

rnamental grasses have recently increased in popularity in the landscape and nursery industry (Cameron, 2004; Thetford et al., 2009). Most ornamental grasses are grown in containers, and are inherently more susceptible to winter damage from exposure to cold or freezing temperatures than fieldgrown plants (Perry, 1998). Consequently, some commercial growers in the mid-Atlantic United States experience significant losses of crops such as fountain grass during the overwintering period (I. Brantingham, personal communication; S. Epps, personal communication; M.J. Packett, personal communication).

Thetford et al. (2009) evaluated the landscape performance of HFG in northern Florida [United States Department of Agriculture (USDA) Hardiness Zone 8b] and characterized its performance as marginal or visually acceptable. The performance of fountain grass would likely be impaired in the mid-Atlantic United States, especially in container production systems that are less buffered against cold temperatures. This impairment associated with cold temperatures has been demonstrated in a wide variety of perennials (Dimke et al., 2008). Under these conditions, growers may use thermal blankets, unheated coldframes, and heated greenhouses to protect container-grown plants from damaging winter temperatures (Smith, 2004).

Several cultural factors, such as the use of substrate moisture content (Smith, 2004), protective covers (Perry, 1998), and fertility level (Bilderback and Bir, 2007) have been identified to affect the overwintering survival and spring vigor of containergrown plants. However, the optimal management of these factors for the production of fountain grass has not been identified. Further research on this topic may lead to economical improvements in overwintering survival and subsequent spring vigor for fountain grass growers.

This study was conducted to determine the effect of substrate moisture content, protective covers, and fertilizer application rate on the survival rate and vigor for SFG and two dwarf selections of fountain grass, HFG and LBFG; we use the term "cultivars" to refer to the group. Plants were selected based on popularity, availability, and grower-reported problems with overwintering (I. Brantingham, personal communication; S. Epps, personal communication; M.J. Packett, personal communication).

\section{Materials and methods}

Plant material and cultural MANAgement. On l Sept. 2009, rooted liners of SFG, HFG, and LBFG (Hoffman Nursery, Rougemont, NC) were hand sorted for uniform size 
and transplanted into 3-qt (trade gallon) containers (Elite 300; ITML Horticultural Products, Akron, $\mathrm{OH}$ ) using a pinebark:peatmoss (17:3, by volume) substrate provided by Riverbend Nursery (Riner, VA). After potting, plants were placed in a quonset-style coldframe structure covered with a single layer of 4-mil opaque white polyethylene (Ginegar Plastic Products, Piqua, $\mathrm{OH}$ ) at the Virginia Tech Urban Horticulture Center [Blacksburg, VA (USDA Hardiness Zone 6a)]. An extra row of fallow containers were placed around each treatment block to serve as a buffer row, as suggested by Perry (1998). Data loggers (WatchDog ${ }^{\circledR}$; Spectrum Technologies, Plainfield, IL) were used to continually measure substrate temperature and air temperature (in and outside of the coldframe and under protective covers) (Table 1 ) for the duration of the experiment. In accordance with the recommended production practices, plants were pruned back to a height of 4 inches from the substrate surface once completely dormant (complete desiccation).

On 2 Dec. 2009, all plants were treated with a $10-\mathrm{fl} \mathrm{oz}$ preventative fungicide drench of $40 \%$ etridiazole + thiophanate-methyl (Banrot ${ }^{\circledR} 40 \mathrm{WP}$; Everris, Dublin, $\mathrm{OH}$ ) and $22.0 \%$ mefenoxam (Subdue MAXX ${ }^{\mathrm{TM}}$; Syngenta, Basel, Switzerland). On 28 Jan. 2010, all plants were treated with a preventative fungicide spray (applied to runoff) of $38.5 \%$ chlorothalonil (Daconil ULTREX ${ }^{\circledR}$; Syngenta) and $5.0 \%$ azoxystrobin $\left(\right.$ Heritage $^{\circledR}$; Syngenta) to prevent botrytis (Botrytis cinerea) infection.

Fertilizer application rate. At the time of transplant, we incorporated $7 \mathrm{lb} /$ yard $^{3}$ of $15 \mathrm{~N}-3.9 \mathrm{P}-10 \mathrm{~K}$ controlled-release fertilizer [CRF (Osmocote Plus ${ }^{\circledR}$ 15-9-12, 5- to

Department of Horticulture, Virginia Tech, 30 Saunders Hall, Blacksburg, VA 24061

Partial funding was provided by the Virginia Agricultural Council and the Virginia Nursery and Landscape Association.

We thank Hoffman Nursery and Riverbend Nursery for donating materials.

Trade or brand names used in this publication does not constitute a guarantee or warranty of the product by Virginia Tech and does not imply its approval to the exclusion of other products or vendors that also may be suitable.

This publication is a portion of a thesis submitted by William K. Harris in partial fulfillment of the degree of master of science.

${ }^{1}$ Corresponding author. E-mail: perennials@vt.edu.

Table 1. Substrate and air temperature between Dec. 2009 and Mar. 2010 for fountain grass (straight species), 'Hameln' fountain grass, and 'Little Bunny' fountain grass overwintered in a coldframe, when using one of three protective covering treatments.

\begin{tabular}{llccc}
\hline & & \multicolumn{3}{c}{ Temp $\left({ }^{\circ} \mathbf{C}\right)^{\mathrm{z}}$} \\
\cline { 3 - 5 } Covering & \multicolumn{1}{c}{ Location } & Minimum & Mean & Maximum \\
\hline- & Air outside coldframe & -17.8 & 7.8 & 29.4 \\
\multirow{2}{*}{ No cover } & Air inside coldframe & -10.9 & 7.2 & 37.7 \\
& Air at pot height & -10.9 & 3.9 & 31.5 \\
Insulation fabric & Substrate & -6.9 & 4.0 & 20.5 \\
& Air under cover & -7.9 & 4.3 & 35.3 \\
Insulation fabric + poly $^{\mathrm{w}}$ & Substrate & -0.3 & 4.3 & 27.9 \\
& Air under cover & -8.4 & 4.0 & 28.9 \\
& Substrate & -0.1 & 4.0 & 20.4 \\
\hline
\end{tabular}

${ }^{2}\left(1.8 \times{ }^{\circ} \mathrm{C}\right)+32={ }^{\circ} \mathrm{F}$.

youtside air temperature measured between Nov. 2009 and May 2010

${ }^{x}$ Double layer of $1.5-\mathrm{oz} / \mathrm{yard}^{2}\left(50.86 \mathrm{~g} \cdot \mathrm{m}^{-2}\right)$ insulation fabric.

${ }^{w}$ Double layer of $1.5-\mathrm{oz} / \mathrm{yard}^{2}$ insulation fabric plus a single layer of 4-mil $(0.1 \mathrm{~mm})$ white polyethylene.

6-month longevity; Everris)], which served as the low fertilizer application rate. An additional $5 \mathrm{lb} / \mathrm{yard}^{3}$ of $15 \mathrm{~N}-$ 3.9P-10K CRF (Polyon ${ }^{\circledR}$ 15-9-12; 5-to 6-month longevity; Harrell's, Lakeland, FL) was incorporated into a portion of the substrate for a total of $12 \mathrm{lb} /$ yard $^{3} \mathrm{CRF}$, which served as the high rate. Substrate solution was collected 2 weeks after transplanting (15 Sept. 2009) and during the following spring (15 May 2010) via the pourthrough extraction method (Wright, 1986). A handheld meter (HI9812; Hanna Instruments, Woonsocket, RI) was used to determine the $\mathrm{pH}$ and electrical conductivity (EC) of the substrate solution (Table 2).

Substrate MOISTURE CONTENT. Substrate VWC was measured twice per week by inserting a soil moisture probe (WaterScout ${ }^{\circledR}$ SM 100; Spectrum Technologies) $8 \mathrm{~cm}$ into the substrate. The results of a preliminary dry-down experiment (data not shown) were used to set a wet and dry $(25 \%$ and $15 \%$ VWC, respectively) threshold. When the substrate of five randomly sampled containers was at or below the respective threshold, the plants received overhead irrigation that generated a leaching fraction of $20 \%$ to $30 \%$.
Protective covering. At the onset of dormancy (determined at point when foliage of all plants had turned light tan), 1 Dec. 2009, plants received one of three protective covering treatments including 1) a double layer of $1.5-\mathrm{oz} / \mathrm{yard}^{2}$ insulation fabric (N-Sulate ${ }^{\mathrm{TM}}$; DeWitt Co., Sikeston, MO), 2) a double layer of insulation fabric plus a single sheet of 4-mil white polyethylene (Ginegar Plastic Products) placed above the insulation fabric, or 3 ) a control treatment, receiving no protective cover. Covers were applied when the overnight temperature was forecast to be $-6.6{ }^{\circ} \mathrm{C}$ or lower. The covers were removed when the temperature was above this threshold, as recommended by Still et al. (1987).

EXPERIMENTAL DESIGN, DATA COLleCtion, AND ANALYSIS. The experiment was a 2 (substrate moisture content $) \times 3($ covering $) \times 3$ (cultivar $) \times$ 2 (fertilizer rate) factorial, arranged as a split-plot design with substrate moisture content as a whole plot factor, and covering as the subplot factor, with plant cultivar as the sub-subplot factor and fertilizer rate as the sub-subsubplot factor (Fig. 1). The subfactor treatment (coverings) was randomized within each main plot factor. Plant

\begin{tabular}{llll}
\hline $\begin{array}{l}\text { Units } \\
\begin{array}{l}\text { To convert U.S. to SI, } \\
\text { multiply by }\end{array}\end{array}$ & U.S. unit & SI unit & $\begin{array}{l}\text { To convert SI to U.S., } \\
\text { multiply by }\end{array}$ \\
\hline 29.5735 & $\mathrm{fl} \mathrm{oz}$ & $\mathrm{mL}$ & 0.0338 \\
2.54 & inch $(\mathrm{es})$ & $\mathrm{cm}$ & 0.3937 \\
0.5933 & $\mathrm{lb} / \mathrm{yard}^{3}$ & $\mathrm{~kg} \cdot \mathrm{m}^{-3}$ & 1.6856 \\
0.0254 & $\mathrm{mil}$ & $\mathrm{mm}$ & 39.3701 \\
1 & $\mathrm{mmho} / \mathrm{cm}$ & $\mathrm{mS} \cdot \mathrm{cm}^{-1}$ & 1 \\
33.9057 & $\mathrm{oz} / \mathrm{yard}^{2}$ & $\mathrm{~g} \cdot \mathrm{m}^{-2}$ & 0.0295 \\
0.9464 & $\mathrm{qt}$ & $\mathrm{L}$ & 1.0567 \\
$\left({ }^{\circ} \mathrm{F}-32\right) \div 1.8$ & ${ }^{\circ} \mathrm{F}$ & ${ }^{\circ} \mathrm{C}$ & $\left({ }^{\circ} \mathrm{C} \times 1.8\right)+32$
\end{tabular}


Table 2. Effect of substrate moisture, covering, cultivar selection, and fertility on the vigor rating of container-grown fountain grasses including fountain grass (straight species) (SFG), 'Hameln' fountain grass (HFG), and 'Little Bunny' fountain grass (LBFG) overwintered in a coldframe, when using one of three protective covering treatments: a double layer of $1.5-\mathrm{oz} / \mathrm{yard}^{2}\left(50.86 \mathrm{~g} \cdot \mathrm{m}^{-2}\right)$ insulation fabric, a double layer of insulation fabric plus a single sheet of 4-mil $(0.1 \mathrm{~mm})$ white polyethylene film (poly) placed above the insulation fabric, or a control treatment (no cover).

\begin{tabular}{|c|c|c|c|c|}
\hline & df & \multicolumn{3}{|c|}{ Vigor $(1 \text { to } 5 \text { scale })^{\mathrm{z}}$} \\
\hline Substrate moisture ${ }^{\mathrm{y}}$ & 1 & & & \\
\hline Wet & & & $2.5 \mathrm{a}^{\mathrm{x}}$ & \\
\hline Dry & & & $2.2 \mathrm{~b}$ & \\
\hline Substrate moisture effect & & & 0.0437 & \\
\hline Error (substrate moisture) & 5 & & & \\
\hline Covering & & SFG & $\mathrm{HFG}$ & LBFG \\
\hline No covering & & $1.5 \mathrm{~b}$ & $2.3 \mathrm{~b}$ & $1.0 \mathrm{~b}$ \\
\hline Insulation fabric & & $3.4 \mathrm{a}$ & $3.3 \mathrm{a}$ & $1.6 \mathrm{a}$ \\
\hline Insulation fabric + poly & & $3.2 \mathrm{a}$ & $3.5 \mathrm{a}$ & $1.5 \mathrm{a}$ \\
\hline Covering effect & & $<0.0001$ & 0.0021 & 0.0004 \\
\hline Substrate moisture $\times$ covering & 2 & & 0.8341 & \\
\hline Error (covering) & 20 & & & \\
\hline Cultivar & 2 & & & \\
\hline SFG & & & $2.7 \mathrm{~b}$ & \\
\hline HFG & & & $3.0 \mathrm{a}$ & \\
\hline LBFG & & & $1.3 \mathrm{c}$ & \\
\hline Cultivar effect & & & $<0.0001$ & \\
\hline Substrate moisture $\times$ cultivar & 2 & & 0.2000 & \\
\hline Covering $\times$ cultivar & 4 & & 0.0103 & \\
\hline $\begin{array}{l}\text { Substrate moisture } \times \text { covering } \times \\
\text { cultivar }\end{array}$ & 4 & & 0.0338 & \\
\hline Error (cultivar) & 60 & & & \\
\hline Fertility $^{\mathrm{w}}$ & 1 & SFG & $\mathrm{HFG}$ & LBFG \\
\hline Low & & $3.3 \mathrm{a}$ & $3.6 \mathrm{a}$ & $1.6 \mathrm{a}$ \\
\hline High & & $2.1 \mathrm{~b}$ & $2.5 \mathrm{~b}$ & $1.1 \mathrm{~b}$ \\
\hline Fertility effect & & 0.0023 & 0.0002 & 0.0012 \\
\hline Fertility & & No covering & Insulation & Insulation + poly \\
\hline Low & & 1.8 & $3.3 \mathrm{a}$ & $3.3 \mathrm{a}$ \\
\hline High & & 1.4 & $2.2 \mathrm{~b}$ & $2.1 \mathrm{~b}$ \\
\hline Fertility effect & & 0.2142 & 0.0002 & 0.0005 \\
\hline Substrate moisture $\times$ fertility & 1 & & 0.2353 & \\
\hline Covering $\times$ fertility & 2 & & 0.0154 & \\
\hline Cultivar $\times$ fertility & 2 & & 0.0490 & \\
\hline $\begin{array}{l}\text { Substrate moisture } \times \text { covering } \times \\
\text { fertility }\end{array}$ & 2 & & 0.4380 & \\
\hline $\begin{array}{l}\text { Substrate moisture } \times \text { cultivar } \times \\
\text { fertility }\end{array}$ & 2 & & 0.8100 & \\
\hline Covering $\times$ cultivar $\times$ fertility & 4 & & 0.9401 & \\
\hline $\begin{array}{l}\text { Substrate moisture } \times \text { covering } \times \\
\text { cultivar } \times \text { fertility }\end{array}$ & 4 & & 0.7641 & \\
\hline Error (fertility) & 90 & & & \\
\hline Total errors & 215 & & & \\
\hline
\end{tabular}

${ }^{\mathrm{z}}$ Adapted from Cunliffe and Meyer (2002).

ySubstrate moisture treatments were wet [25\% volumetric moisture content (VMC)] or dry (15\% VMC).

${ }^{x}$ Means within the same column followed by the same letter are not significantly different at $\alpha=0.05$ by Tukey's honestly significant difference multiple comparison at $P<0.05$.

"Low and high controlled-release fertilizer rates were incorporated at 7 and $12 \mathrm{lb} /$ yard $^{3}$, respectively; $1 \mathrm{lb} /$ yard $^{3}=$ $0.5933 \mathrm{~kg} \cdot \mathrm{m}^{-3}$.

cultivars and fertilizer rate treatments were blocked within each subplot factor of covering.

On 15 May 2010, plants were evaluated to determine the percent survival. At this time plants were also sub-subplot and fertility rate as the sub-sub-subplot. An analysis of variance was performed using JMP (version 8; SAS Institute, Cary, NC) using the full factorial response design. Mean comparisons were performed using Tukey's honest significant difference test.

\section{Results and discussion}

Substrate moisture, covering, cultivar selection, and fertility all influenced the vigor rating of container-grown fountain grasses (Table 2). Cultivar selection proved to have a strong influence on the spring vigor of the overwintered grasses, regardless of substrate moisture, covering, or fertility. 'Hameln' fountain grass received the highest vigor rating (3.0), SFG showed a slight, yet significant reduction in rating (2.7), whereas LBFG received the lowest vigor rating (1.3). 'Little Bunny' had the lowest overall survival rate (Table 3 ), which is reflected in the low vigor rating (dead plants were given a vigor rating of 1 ). A saleable plant would have a rating of 4 or greater (defined as having growth more than half the diameter of the old crown; Fig. 2). However, all plants in our study averaged a vigor rating of 3.0 or less. This was expected, as cultivars were selected that were specifically identified by growers as having difficulty overwintering, which was evident in our results.

For all of the cultivars, the covered plants rated significantly higher in both vigor and survival percentage than the uncovered plants, though cover type (insulation alone or insulation + polyethylene) was not influential (Table 2). The higher percentage of plants that survived when either protective covering method was used, relative to when no cover was used, may have resulted from a temperature buffering effect induced by the protective covers. Perry (1998) stated that protective covers in a coldframe may create a microclimate around plants, where the air under the cover may be 4.4 to $5.5^{\circ} \mathrm{C}$ warmer than the air above the cover. The temperature data from this study revealed a similar effect, as the air temperature under the cover was $3{ }^{\circ} \mathrm{C}$ warmer than the air outside of the cover when a double layer of insulation fabric was used, and $1.5{ }^{\circ} \mathrm{C}$ higher when a double layer of insulation fabric + white polyethylene was used (Table 1). A similar effect was seen with regard to substrate temperature, in that the minimum substrate given a vigor rating, using a visual scale of 1-5 developed by Cunliffe and Meyer (2002) (Fig. 2). Data were analyzed as a split-plot design with substrate moisture as the whole plot, cover as the subplot, cultivar as the 


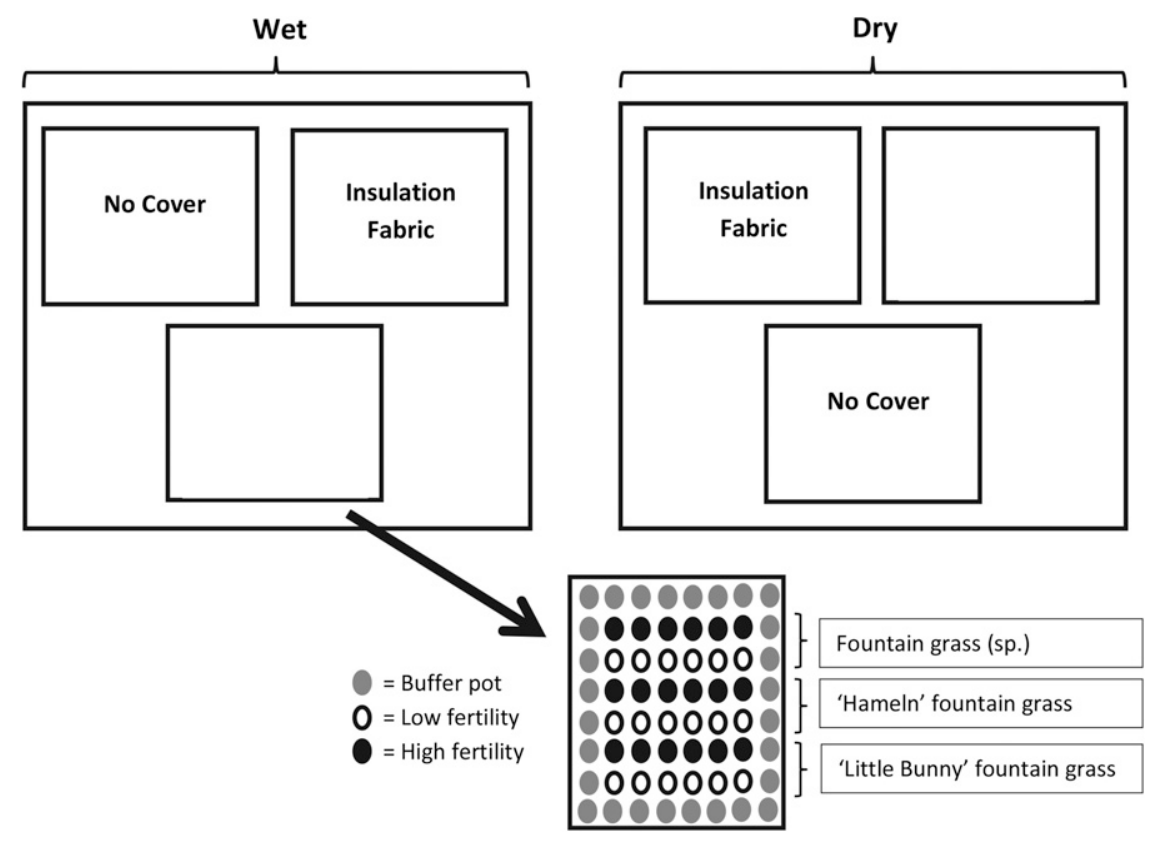

Fig. 1. Experimental design for fountain grass overwintering experiment: substrate moisture (wet or dry) was set up as the main factor, three protective covering treatments [double layer of $1.5-\mathrm{oz} / \mathrm{yard}^{2}\left(50.09 \mathrm{~g} \cdot \mathrm{m}^{-2}\right)$ insulation fabric, a double layer of insulation fabric plus a single sheet of $4-\mathrm{mil}(0.1 \mathrm{~mm})$ white polyethylene film (poly) placed above the insulation fabric, or a control treatment (no cover)] as the subfactor, and two fertilizer treatments (low and high) as the sub-subfactor. Fountain grass straight species (sp.) along with fountain grass cultivars Hameln and Little Bunny were blocked within each subfactor of covering. There were six replications of each fertilizer treatment. Buffer plants were used to surround each covering treatment to minimize edge effects.

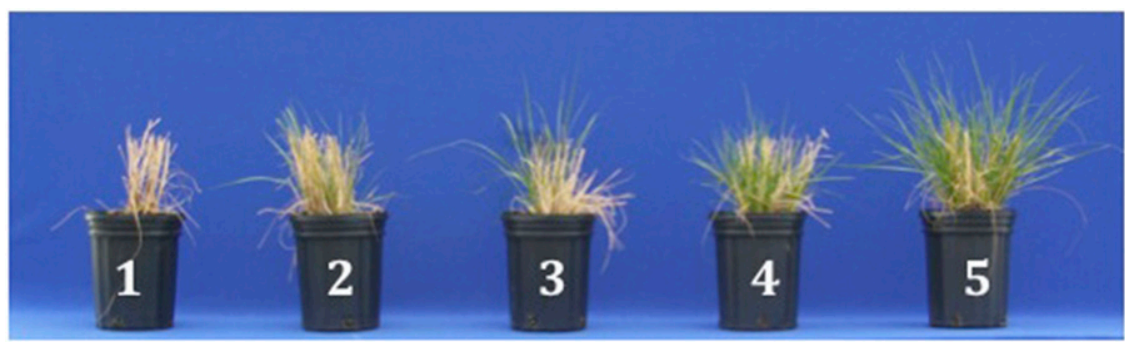

Rating scale used to evaluate the vigor of fountain grass cultivars.

\begin{tabular}{lll} 
Rating & Growth & New crown diameter \\
\hline 1 & Dead & Less than half the diameter of the old crown \\
3 & Diffuse & Less than half the diameter of the old crown \\
4 & Diffuse & More than half the diameter of the old crown \\
5 & Expansive & More than half the diameter of the old crown \\
\hline
\end{tabular}

Fig. 2. Rating scale used to evaluate the vigor of fountain grass (adapted from Cunliffe and Meyer, 2002).

temperature was $\approx 6.7{ }^{\circ} \mathrm{C}$ higher in treatments that involved either protective covering method, as compared with treatments without cover (Table 1 ). This temperature buffering effect may have reduced crop exposure to extreme air and substrate temperatures, and subsequently reduced winter damage to plant tissue.

Fertility levels influenced both the vigor and survival percentage of all cultivars of fountain grass used in the study. The higher fertility treatment resulted in reduced vigor ratings for each cultivar (Table 2) and reduced the percentage of plants that survived (Table 3). A limited amount of research has been published on fertilizer management strategies that maximize the overwinter survival rate of fountain grass. However, some grower-led trials have suggested that a relatively low fertilizer application rate that resulted in a substrate solution EC of 0.6 to 1.5 $\mathrm{mS} \cdot \mathrm{cm}^{-1}$ was optimal (Emerald Coast Growers, 2010; Proven Winners, 2011; Walters Gardens, 2011). In this study, substrate solution EC was higher than the grower-recommended range at 2 weeks after transplanting (data not shown). However, by the end of the study, substrate solution EC was generally within the growerrecommended range for the low fertilizer application rate and slightly above range for the high fertilizer application rate. These findings suggest a relationship between substrate solution EC and the overwinter survival of fountain grass.

When no cover was used, fertility did not have a significant impact on vigor rating; however, this is could be a result of the low survival rate of the uncovered plants. Therefore, a higher number of vigor ratings of a " 1 ," as opposed to a fertility response. There were no significant interactions between substrate moisture and cultivar, cover, or fertility; therefore, data were pooled to analyze the effect of substrate moisture on plant vigor. The wet substrate moisture treatment resulted in a higher vigor rating than the dry substrate moisture (Table 2). Although significant, the difference in the ratings was minimal; 2.5 and 2.2 for wet and dry, respectively. Further compounding the reliability of the substrate moisture significance is the negligible difference in substrate moistures throughout the winter. Although we had planned to irrigate the treatments when the average substrate moisture fell below $25 \%$ and $15 \%$ VWC, the fountain grasses needed few irrigations throughout the winter to remain above the set thresholds (Fig. 3). Therefore, the difference in substrate moisture was not as significant as planned. Additional research, with a wider range of substrate moisture contents, is needed before drawing definitive conclusions on how substrate moisture affects the overwintering vigor of fountain grasses. 
Table 3. The percent survival rate of container-grown fountain grass including the straight species (SFG), 'Hameln' fountain grass (HFG), and 'Little Bunny' fountain grass (LBFG) overwintered in a coldframe, when using one of three protective covering treatments: a double layer of $1.5-\mathrm{oz} / \mathrm{yard}^{2}\left(50.86 \mathrm{~g} \cdot \mathrm{m}^{-2}\right)$ insulation fabric, a double layer of insulation fabric plus a single sheet of 4-mil $(0.1 \mathrm{~mm})$ white polyethylene film (poly) placed above the insulation fabric, or a control treatment (no cover); two rates of controlled-release fertilizer (CRF), and two substrate moisture levels.

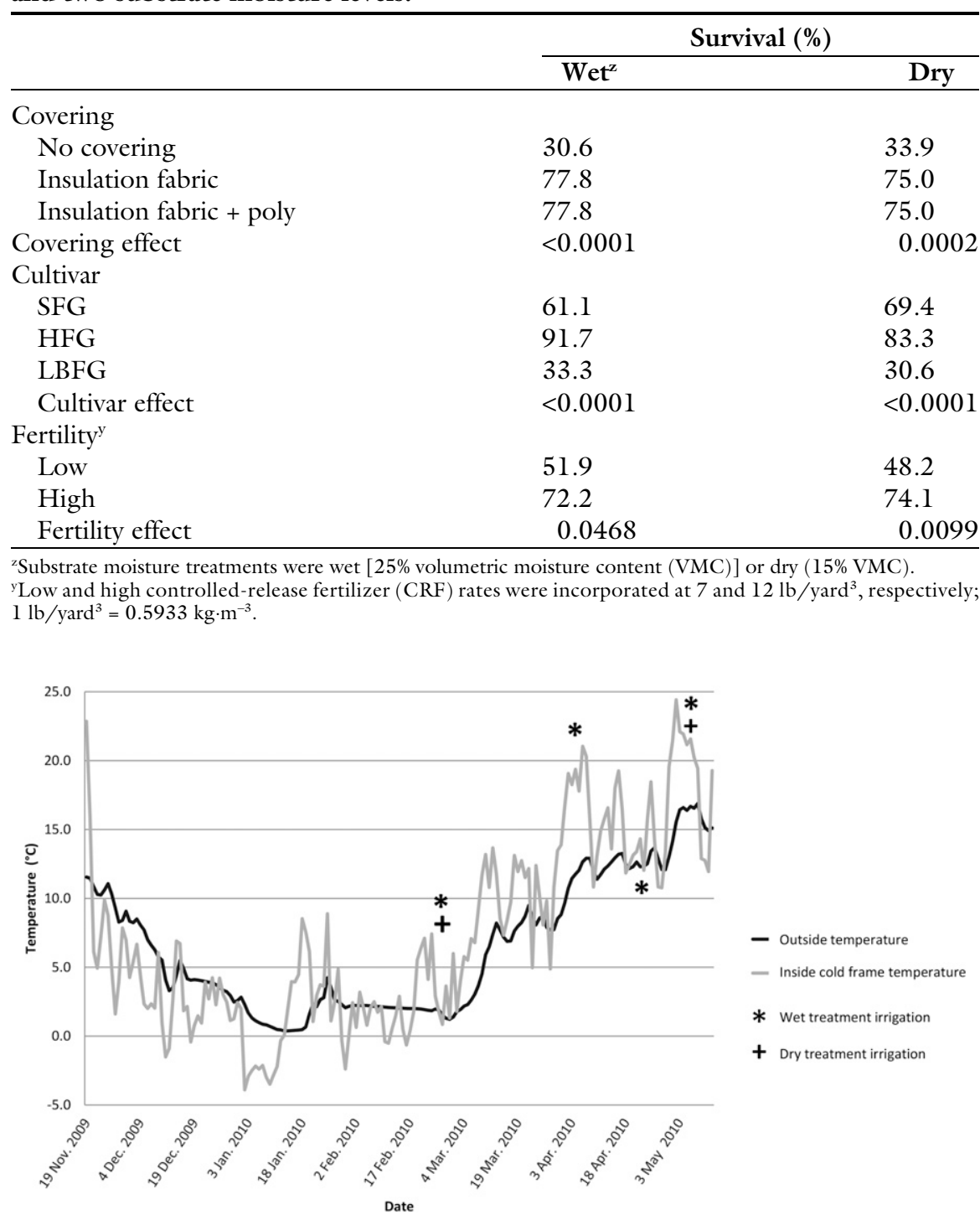

Fig. 3. Outside air temperature and air temperature inside the coldframe at the Urban Horticulture Center (Blacksburg, VA) over the course of the experiment from 19 Nov. 2009 to 8 May 2010 with irrigation events denoted for both the wet substrate moisture treatment $\left({ }^{*}\right)$ and the dry substrate moisture treatment $(+) ;\left(1.8 \times{ }^{\circ} \mathrm{C}\right)+32={ }^{\circ} \mathrm{F}$.

\section{Conclusion}

In general, the most favorable survival rates and vigor ratings were observed in treatments that involved protective covers and low fertility rates. However, the results did not suggest an advantage to using a double layer of insulation fabric and white polyethylene over only a double layer of insulation fabric. Although our study suggests that using a protective cover and low fertility can improve vigor site evaluations to determine the conditions that maximize survival and vigor for the cultivars they grow.

\section{Literature cited}

Bilderback, T. and R. Bir. 2007. Preparing nursery plants for winter. North Carolina Coop. Ext. Serv. Bul. AG-454. 15 Jan. 2011. <http://www.ces.ncsu.edu/ depts/hort/hil/ag454b.html>.

Cameron, A. 2004. Ornamental grasses: A new wave of floriculture crops. Greenhouse Product News 14:50-54.

Cunliffe, B.A. and M.H. Meyer. 2002. Propagation time affects winter survival and finishing date for ornamental grasses. J. Environ. Hort. 20:201-203.

Dimke, K.C., S.K. Still, and D.S. Gardner. 2008. Effect of overwintering environment on the survival of 30 species of herbaceous perennials. J. Environ. Hort. 26:222-228

Emerald Coast Growers. 2010. Grower cultural information for Pennisetum alopecuroides, Pennisetum alopecuroides 'Hameln,' and Pennisetum alopecuroides 'Little Bunny.' 11 June 2011. <http:// www.ecgrowers.com/PennisetumGrasses-s/107.htm>.

Perry, L. 1998. Herbaceous perennials production: A guide from propagation to marketing. Northeast Reg. Agr. Eng. Serv. Publ. NRAES-93.

Proven Winners. 2011. Professional grower resources for Pennisetum alopecuroides. 14 Sept. 2011. <http://www.pwcertified. com/grower/plants $/>$.

Smith, T.M. 2004. Overwintering containerized perennials. 15 Jan. 2011. <http://www.umass.edu/umext/ floriculture/fact_sheets/specific_crops/ overwint.html>.

Still, S.M., T. Disabato-Aust, and G. Brenneman. 1987. Cold hardiness of herbaceous perennials. Proc. Intl. Plant Prop. Soc. 37:386-392.

Thetford, M., J.G. Norcini, B. Ballard, and J.H. Aldrich. 2009. Ornamental landscape performance of native and nonnative grasses under low-input conditions. HortTechnology 19:267-285.

Walters Gardens. 2011. Cultural sheets for Pennisetum alopecuroides and/or orientalis. 14 Sept. 2011. <http://www. waltersgardens.com/growerscorner/? page $=85 \&$ sheet $=94>$.

Wright, R.D. 1986. The pour-through nutrient extraction procedure. HortScience 21:227-229. 